Research Report No. 28/2010

\title{
Does Section 2(B) Really Make a Difference? Part 1: Freedom of Expression, Defamation Law, and the Journalist-Source Privilege
}

Jamie Cameron

Osgoode Hall Law School of York University, jcameron@osgoode.yorku.ca

Follow this and additional works at: http:// digitalcommons.osgoode.yorku.ca/clpe

\section{Recommended Citation}

Cameron, Jamie, "Does Section 2(B) Really Make a Difference? Part 1: Freedom of Expression, Defamation Law, and the JournalistSource Privilege" (2010). Comparative Research in Law \& Political Economy. Research Paper No. 28/2010.

http://digitalcommons.osgoode.yorku.ca/clpe/95 


\section{OSGOODE}

\section{OSGOODE HALL LAW SCHOOL}

Comparative Research in Law \& Political Economy

RESEARCH PAPER SERIES

Research Paper No. 28/2010

DOES SECTION 2(B) REALLY MAKE A DIFFERENCE?

PART 1: FREEDOM OF EXPRESSION, DEFAMATION LAW, AND THE JOURNALIST-SOURCE PRIVILEGE

Jamie Cameron

\section{Editors:}

Peer Zumbansen (Osgoode Hall Law School, Toronto, Director, Comparative Research in Law and Political Economy)

John W. Cioffi (University of California at Riverside)

Lisa Philipps (Osgoode Hall Law School, Associate Dean Research)

Nassim Nasser (Osgoode Hall Law School, Toronto,

Production Editor) 
CLPE Research Paper 28/2010

Vol. 06 No. 6 (2010)

Jamie Cameron

\title{
DOES SECTION 2(b) REALLY MAKE A DIFFERENCE? \\ Part 1: Freedom of expression, defamation law, and the journalist-source privilege
}

\begin{abstract}
The question this article poses is whether the common law must adopt Charterspecific doctrines or remedies when Charter values are at stake. The discussion focuses on the Supreme Court's defamation decisions, but includes brief remarks about R. v. National Post, which considered whether the Wigmore test for a journalist-source privilege is consistent with the Charter.
\end{abstract}

Keywords: Freedom of expression, Defamation, Journalist, Source privilege, Wigmore test, Church of Scientology, WIC Radio, Grant v. Torstar Corp., Cusson v. Quan, Common law, Charter, Supreme Court of Canada, public interest responsible communication

JEL Classification: K 39

Supreme Court Law Review [forthcoming]

\author{
Jamie Cameron \\ Professor, Osgoode Hall Law School, \\ Co-chair of the $13^{\text {th }}$ Annual Constitutional Cases Conference \\ Email: jcameron@yorku.ca
}




\section{Freedom of Expression and the Press}





\title{
Does Section 2(b) Really Make a Difference? Part 1: Freedom of Expression, Defamation Law and the Journalist-Source Privilege
}

\author{
Jamie Cameron *
}

\section{DANCING IN THE STREETS}

New York Times v. Sullivan was "an occasion for dancing in the streets", because that is when the U.S. Supreme Court finally declared the Sedition Act of 1798 unconstitutional. ${ }^{1}$ Sullivan also took a revolutionary step in constitutionalizing the law of defamation and conferring protection on those who publish false statements about public officers. ${ }^{2}$ In explaining how the Court's malice rule serves the First Amendment's vital purposes, Brennan J. wrote some of the most memorable passages in the U.S. free speech tradition. ${ }^{3}$

Decades later, the Supreme Court of Canada introduced a defence for "public interest responsible communication" ("PIRC"). ${ }^{4}$ Though less generous than Sullivan's malice rule, the defence allows those who publish false, defamatory statements to avoid liability by establishing that

\footnotetext{
Professor, Osgoode Hall Law School, and co-chair of the 13th Annual Constitutional Cases Conference.

376 U.S. 254 (1964) [hereinafter "Sullivan"]. Harry Kalven, "The New York Times Case: A Note on 'the Central Meaning of the First Amendment"', [1964] S. Ct. Law Rev. 191, at 221, note 125 (quoting Alexander Meiklejohn).

Sullivan introduced the malice rule, which protects defamatory statements about public officers, and public figures under subsequent decisions, unless the statements are made with "actual malice" - knowledge of falseness or with reckless disregard of their status as true or false. Sullivan, id.

3 Kalven predicted that Sullivan "may prove to be the best and most important [opinion the Court] has ever produced in the realm of freedom of speech"; supra, note 1, at 194.

Grant v. Torstar Corp., [2009] S.C.J. No. 61, 2009 SCC 61 (S.C.C.) [hereinafter "Grant"]; Cusson v. Quan, [2009] S.C.J. No. 62, 2009 SCC 62 (S.C.C.) [hereinafter "Cusson"] (December 22, 2009). The Court discussed and defined the PIRC defence in Grant, which is the leading decision as a result. See P. Downard, "The Defence of Responsible Communication", in this volume; B. Tarantino, "Chasing Reputation - The Argument for Differential Treatment of 'Public Figures' in Canadian Defamation Law" (2010) 48 Osgoode Hall L.J. (forthcoming, fall 2010).
} 
the work addresses a matter of public interest and satisfies a standard of "responsible communication". 5 The Supreme Court's decisions in Grant v. Torstar Corp. and Cusson v. Quan were hailed as a key victory for the media and a major advance in defamation law. Yet, as the Ottawa Citizen's lawyer declared, if the Court had not taken that step the law in this country would be "in the Dark Ages". ${ }^{6}$ The Court itself admitted that Canada's law of defamation lagged behind that of its common law peers. $^{7}$ It was a remarkable feat, considering that others, such as the United Kingdom, New Zealand and Australia, do not have a constitutional bill of rights. Rather than place it in the vanguard, the Canadian Charter of Rights and Freedoms held the law of defamation in this country back. ${ }^{8}$ If there were celebratory jigs when Grant and Cusson were decided, there were sighs of relief as well.

In its first look at defamation under the Charter in 1995, the Court got its priorities wrong and put reputation ahead of expressive freedom. Justice Cory wrote forcefully in Hill v. Church of Scientology that the law of defamation did not require modification, because false, defamatory statements have minimal value and do not offset the law's interest in protecting reputation. ${ }^{9}$ In this way, the Charter unexpectedly served as a negative force, and the evolution of doctrine came to a halt after Church of Scientology. Meantime, the House of Lords in the U.K. introduced the concept of responsible journalism in Reynolds v. Times Newspapers, and courts in Australia, New Zealand and South Africa found other ways to strengthen expressive freedom in defamation law's balancing of interests. $^{10}$

Twice in recent years the Supreme Court stepped away from Church of Scientology with corrections of its own. First it modernized the fair

5 The Court proposed a two-part test and listed seven elements of "responsible communication", but cautioned that the list was not exhaustive of the criteria for determining that question. Grant, id., at para. 126 (summarizing the criteria).

6 P. McGrath, "Canada's Supreme Court establishes new libel defence", The National Post (December 23, 2009) (quoting Ottawa Citizen lawyer Richard Deardon).

7 Grant, supra, note 4, at paras. 66, 69, and 85.

8 Part I of the Constitution Act, 1982, being Schedule B to the Canada Act 1982 (U.K.), 1982, c. 11 [hereinafter "Charter"].

9 Hill v. Church of Scientology of Toronto, [1995] S.C.J. No. 64, [1995] 2 S.C.R. 1130 (S.C.C.) [hereinafter "Church of Scientology" or "Scientology"]. The Court did expand the definition of qualified privilege to include pleadings not yet filed; infra, note 28.

${ }_{10}$ See Reynolds v. Times Newspapers Ltd., [1999] 4 All E.R. 609 [hereinafter "Reynolds"] and Jameel v. Wall Street Journal Europe SPRL, [2007] 1 A.C. 359 [hereinafter "Jameel"]; for developments in other countries see Grant, supra, note 4, at paras. 77-85. 
comment doctrine in WIC Radio Ltd. v. Simpson, ${ }^{11}$ and then it introduced the PIRC defence in Grant and Cusson. Though these decisions gave expressive freedom a lift in the defamation calculus, all three arose under the common law and none were Charter cases per se. Each time the Court cited section 2(b)'s underlying values, but failed to take the next step of importing Charter analysis or standards into the common law. On the question of fair comment, for instance, WIC Radio turned to Dickson J.'s dissent in Cherneskey v. Armadale Publishers, which was decided before the Charter. ${ }^{12}$ Then Grant imported a British doctrine into domestic law without considering whether modifications to accommodate the Charter were necessary.

The Court's approach in these cases stands in contrast with Dagenais v. Canadian Broadcasting Corporation, which developed a constitutional doctrine when the common law failed to protect expressive freedom. ${ }^{13}$ The issue there was whether a publication ban should be granted to protect an accused's right to a fair trial. After noting that fair trial held the advantage at common law, Lamer C.J.C. held that the test had to be rebalanced and constitutionalized to protect freedom of expression. Under the Charter, a publication ban cannot be granted to protect an accused's right to a fair trial, unless prescribed constitutional requirements are met. ${ }^{14}$ In this way, Dagenais set a vibrant and demanding standard of justification for limits on expressive freedom. As such, it stands as an exemplar of Charter methodology and has served as a model in other settings, including the exercise of discretion under statutory provisions. ${ }^{15}$

11 [2008] S.C.J. No. 41, [2008] 2 S.C.R. 420 (S.C.C.) [hereinafter "WIC Radio"]. With Matthew Milne-Smith and John McCamus, I appeared as counsel for the Canadian Civil Liberties Association ("CCLA") as an intervener in the appeal at the Supreme Court of Canada.

${ }_{12}$ [1978] S.C.J. No. 115, [1979] 1 S.C.R. 1067 (S.C.C.) [hereinafter "Cherneskey"].

13 [1994] S.C.J. No. 104, [1994] 3 S.C.R. 835 (S.C.C.) [hereinafter "Dagenais"].

14 The Court developed a common law test which incorporated the requirements of the Oakes test (R. v. Oakes, [1986] S.C.J. No. 7, [1986] 1 S.C.R. 103 (S.C.C.)):

[A] publication ban cannot be granted unless (a) such a ban is necessary in order to prevent a real and substantial risk to the fairness of the trial, because reasonably available alternative measures will not prevent the risk; and (b) the salutary effects of the publication ban outweigh the deleterious effects to the free expression of those affected by the ban.

Id., at 878 (emphasis in original).

See also Canadian Broadcasting Corp. v. New Brunswick (Attorney General), [1996] S.C.J. No. 38, [1996] 3 S.C.R. 480 (S.C.C.); R. v. Mentuck, [2001] S.C.J. No. 73, [2001] 3 S.C.R. 442 (S.C.C.); R. v. O.N.E., [2001] S.C.J. No. 74, [2001] 3 S.C.R. 478 (S.C.C.); Re Vancouver Sun, [2004] S.C.J. No. 41, [2004] 2 S.C.R. 332 (S.C.C.); and Toronto Star Newspapers Ltd. v. Ontario, [2005] S.C.J. No. 41, [2005] 2 S.C.R. 188 (S.C.C.). 
The Court's most recent decisions on expressive freedom and the common law bear little resemblance to Dagenais. In WIC Radio and Grant, as well as in R. v. National Post ${ }^{16}$ the Court discussed section 2(b)'s underlying values approvingly, but took no steps to incorporate constitutional standards into common law doctrine. The question this article poses, as a result, is whether the Charter really made a difference in these cases. ${ }^{17}$ Specifically, it asks whether the common law must adopt Charter-specific doctrines or remedies when Charter values are at stake.

The discussion focuses on the Court's defamation decisions, but includes brief remarks about $R$. v. National Post, which considered whether the Wigmore test for a journalist-source privilege is consistent with the Charter. It begins in the next section by showing not only that Church of Scientology had a chilling effect on the law of defamation, but also that it influenced the Court's perception of the relationship between the common law and the Charter. The section which follows discusses WIC Radio, the fair comment case that facilitated the transition from Church of Scientology to Grant. There, the Court began to distance itself from Scientology's defence of reputation, but remained unwilling to reconceptualize the fair comment doctrine. The central part of the article considers Grant and the decision to create a new defence in the law of defamation. With Church of Scientology as the baseline, the PIRC defence must be seen as a step forward. Yet, by uncritically adopting the British doctrine of responsible journalism, the Supreme Court chose to follow rather than to lead, and to settle for a common law solution in lieu of a Charterspecific standard. ${ }^{18}$

In upholding coercive searches against the press under the Criminal Code ${ }^{19}$ the Court's most recent decision in National Post rejected the section 2(b) claim, and refused to alter or constitutionalize the common law test for journalist-source privilege. Once again the Court paid its

16 [2010] S.C.J. No. 16, 2010 SCC 16 (S.C.C.) [hereinafter "National Post"]. I appeared before the Supreme Court of Canada in this case, again on behalf of the CCLA, and with Matthew Milne-Smith and John McCamus.

17 This article is the first of two, which together explore the question, "Do Constitutional Rights Really Make a Difference? Expressive Freedom under Section 2(b) of Canada's Charter of Rights and Freedoms" (presented at the Centre for Comparative Constitutional Studies, University of Melbourne law faculty, February 25, 2010). The title derives from the late Justice Bertha Wilson's famous speech at Osgoode Hall Law School, "Will Women Judges Really Make A Difference?" (1990) 28 Osgoode Hall L.J. 507.

${ }_{18}$ Though it is called responsible communication, rather than responsible journalism, the Supreme Court's PIRC defence is virtually indistinguishable from its British counterpart. Infra, note 81.

19 R.S.C. 1985 , c. C-46. 
respects to the Charter, but held that it was unnecessary to re-work the Wigmore test or set it in a constitutional framework. Though section 2(b) may influence the balancing of values in determining the existence of a privilege, the law remains the same and journalist-source relationships are without constitutional status.

National Post confirms the Court's ongoing reluctance to harmonize the common law and the Charter. On all three questions discussed in this article - namely, fair comment, qualified privilege, and the journalistsource relationship - the Court could, and should, have followed Dagenais and made constitutional adjustments to common law doctrine. Instead, the Court held that it suffices for section 2(b)'s values to be taken into account in a discretionary, informal and unstructured way, when expressive freedom is balanced against other interests. If the Charter made a difference in these cases, it was only at the margins, and not in the design and content of doctrine. The Court's reluctance to consider common law reforms which directly respond to the Charter's requirements suggests that judge-made solutions are not the answer, and points to the need for legislative reform in the law of defamation, as well as on the question of journalist-source relationships, or the reporter's privilege.

\section{CHURCH OF SCIENTOLOGY: A GOOD REPUTATION IS "CHERISHED ABOVE ALL"20}

It is too late to turn the clock back now, and ask what Canada's law of defamation might have looked like if the Court had not pushed back as it did in Hill v. Church of Scientology. Shortly after introducing the Dagenais test in a criminal setting, the Court reacted with hostility to the suggestion that the tort of defamation should be constitutionalized. Justice Cory's reasons in Church of Scientology began by finding that the Charter did not apply, as the litigation was between private parties and did not engage the plaintiff's status or responsibilities as a public officer. ${ }^{21}$ In this way he discounted the Charter, though the plaintiff held public office and the defamatory comments addressed his actions as a Crown Attorney. Albeit malicious, Scientology's critique nonetheless

\footnotetext{
20 Church of Scientology, supra, note 9, at para. 107.

$I d$., at paras. 65-82 (stating, at para. 72 , that "[ $\mathrm{t}]$ he fact that persons are employed by the government does not mean that their reputation is divided into two parts, one related to their personal life and the other to their employment status", and adding, that "[r]eputation is an integral and fundamentally important aspect of every individual" which "exists for everyone quite apart from employment").
} 
spoke to section 2(b)'s core values: the accountability of government, Crown prosecutors and the justice system.

After pre-empting the Charter, Cory J. conducted an analysis of Charter values which minimized their influence on the common law. ${ }^{22}$ Before doing so, he spoke of the need for a formal distinction between Charter rights and Charter values, and stated that the Court should take care "not to expand the application of the Charter". ${ }^{23}$ Justice Cory also stressed that in "private" litigation the party relying on the common law should not be required to defend prevailing doctrine. Rather, it rests on those who challenge the common law not only to show that doctrine is inconsistent with the Charter, but also to demonstrate that it is unjustifiable and must be modified. ${ }^{24}$

Having created those obstacles to reform, Cory J. undertook a weighing of values that gave expressive freedom no additional protection because of the Charter. To the contrary, he marginalized the expressive activity at stake and enhanced the status of reputation in the process. Though reputation was already ahead at common law, the "contextual approach" in section 2(b) decision-making contemplated a comparative assessment of values. ${ }^{25}$ When Cory J. applied that methodology to the "twin values" at issue in Church of Scientology, the contrast could scarcely have been greater. He wrote in glowing terms about reputation, describing it as an attribute to be "cherished above all", and pronouncing its protection a matter "of fundamental importance to our democratic society" ${ }^{26}$ At the same time, he discounted defamatory statements as being "tenuously related to the core values which underlie s. 2(b)", and declared such statements to be "detrimental to the advancement of those values and harmful to the interests of a free and democratic society". ${ }^{27}$ Though freedom of expression is protected by the Charter and reputation is not, Cory J. concluded that "there is no need to amend or alter" the

\footnotetext{
$22 \quad$ Id., at paras. $90-99$. 
common law of defamation. ${ }^{28}$ From there he went on to find fault with the Sullivan rule, ${ }^{29}$ confirm the status quo, ${ }^{30}$ and reject a cap on damages. $^{31}$

Justice Cory did not conceal his distaste for the Church of Scientology's behaviour, and nor was he reluctant to show his sympathy for Casey Hill. ${ }^{32}$ The plaintiff was a lawyer, a Crown attorney, and an officer of the court who became a judge, and the Church of Scientology's attacks against him were egregiously and knowingly false. Yet the jury verdict and award, which included aggravated and punitive damages, meant that the Court did not have to choose between a deserving plaintiff and reforms to the law. ${ }^{33}$ Though modifications would not have disturbed the verdict, the Court insisted that the law of defamation did not need to accommodate the Charter. ${ }^{34}$

Church of Scientology placed a chill on expressive freedom which was reinforced by Botiuk v. Toronto Free Press, which was decided a few months later, ${ }^{35}$ and R. v. Lucas, which upheld the Criminal Code's defamatory libel provision. ${ }^{36}$ Justice Cory's majority opinion in Lucas once again focused on the target of the remarks, and in doing so overlooked

28 Id., at para. 141 (emphasis added). Justice Cory expanded the concept of qualified privilege to a lawyer's publication of allegations contained in pleadings which had not yet been filed; id., at paras. 149-154.

${ }_{29}$ Id., at paras. 122-133 (stating, at para. 127, that the actual malice rule "has been severely criticized by American judges and academic writers", and that the decision may have been "overly influenced by the dramatic facts underlying the dispute" and "has not stood the test of time" as a result).

$30 \quad I d$., at para. 137 (stating, "I simply cannot see that the law of defamation is unduly restrictive or inhibiting", and adding, at para. 141, that "the common law ... complies with the underlying values of the Charter").

$31 \quad$ Id., at paras. 167-173.

32 See $i d$., at paras. 178 and 166 (stating that "[i]t would be hard to imagine a more difficult situation for the defamed person to overcome"), as well as para. 156 (describing the Scientology lawyer's conduct as "high-handed and careless"), and para. 184 (declaring, in summary, that "every aspect of this case demonstrates the very real and persistent malice of Scientology").

33 Id., at para. 194 (upholding aggravated damages because "every aspect of this case demonstrates the real and persistent malice of Scientology"), and at para. 200 (stating that Scientology's conduct was "so outrageous" that it "cried out for the imposition of punitive damages").

34 See, e.g., Theophanous v. Herald \& Weekly Times Ltd. (1994), 124 A.L.R. 1 (H.C.A.) (the Court cited Theophanous, id., at para. 135, to show that Australia had also rejected Sullivan, but without considering an alternative to the malice rule, because Church of Scientology did not involve the media or deal with political commentary about government policies; id., at 139).

35 Botiuk v. Toronto Free Press Publications Ltd., [1995] S.C.J. No. 69, [1995] 3 S.C.R. 3 (S.C.C.). Scientology was decided on July 20, 1995, and Botiuk, on September 21, 1995. Like Scientology, Botiuk upheld the libel claim, including an award of aggravated damages, and rejected the defence of qualified privilege.

36 [1998] S.C.J. No. 28, [1998] 1 S.C.R. 439 (S.C.C.) (with the exception of s. 299(c), upholding ss. 298, 299 and 300 of the Criminal Code, R.S.C. 1985, c. C-46). 
the connection between a placard accusing a police officer of misdeeds, and the public interest in holding law enforcement officers accountable. The placard was offensive, but the defendants were seeking redress for a miscarriage of justice, and the Code provisions, in any event, were flawed.

In combination, these decisions entrenched the view that defamatory statements are valueless and do not deserve protection under the Charter. ${ }^{37}$ Justice Cory's opinions in Church of Scientology, Botiuk and Lucas were so unequivocal that it was difficult for the Court to attempt change, no matter how modest or incremental. Several years would pass before the Supreme Court was willing to take another look, and by then substantial changes in the law of defamation had taken place elsewhere. In the circumstances, almost any modification of Canadian doctrine would represent a step forward for expressive freedom. For that reason, the issue in this article is not whether WIC Radio and the PIRC cases marked progress, as both did. More to the point, the question is whether these decisions give expressive freedom the protection that is required by the Charter. The discussion which follows suggests that there is reason to doubt that they do.

\section{WIC RADIO: PUBLIC CONTROVERSY Is A ROUGH TRADE ${ }^{38}$}

The fair comment doctrine applies to opinions or comments, rather than statements of fact, and allows the publisher to avoid responsibility for stating a point of view on a matter of public interest, as long as the opinion is based on facts and is grounded in an "honest belief". ${ }^{39}$ When the doctrine reached the top Court in WIC Radio Ltd. v. Simpson, it was the first time since Cherneskey, and the first time under the Charter. ${ }^{40}$ It is remarkable that Cherneskey survived almost 30 years, given the Court's decision in that case to hold a newspaper liable for publishing a letter to the editor. Fair comment was not available to the publisher there because of a gap in the evidence. The authors of the offending letter did not appear as witnesses at trial, and the newspaper and its editor quickly distanced

\footnotetext{
37 But see R. v. Zundel, [1992] S.C.J. No. 70, [1992] 2 S.C.R. 731 (S.C.C.) (invalidating the Criminal Code prohibition on the wilful spreading of false news).

38 WIC Radio, supra, note 11, at para. 15.

39 Id., at para. 1 (outlining the elements of the doctrine). Fair comment is subject to malice and will not be available where the plaintiff proves that the defendant acted with malice in publishing a defamatory comment.

40 Cherneskey, supra, note 12.
} 
themselves from the letter's opinion that the plaintiff — Cherneskey was a racist. ${ }^{41}$ Fair comment could not be established without evidence of honest belief, and that created a dilemma for newspapers which were left with two choices, both undesirable. To avoid liability for letters to the editor, a newspaper could satisfy honest belief either by adopting every point of view it published, or not publishing opinions it disagreed with at all. Cherneskey was so chilling that a number of legislatures moved quickly to enact measures reversing the Court's decision. ${ }^{42}$

WIC Radio was the first defamation case to reach the Supreme Court after Church of Scientology and Botiuk, but fair comment and honest belief, not false statements of fact, were the key variables. The appeal was brought from a B.C. Court of Appeal decision rejecting fair comment in the case of a radio editorial against an anti-gay activist. ${ }^{43}$ At trial, the judge found that listeners could have concluded that the talk show host, Rafe Mair, thought the plaintiff condoned the use of violence against gays. ${ }^{44}$ Mair neither believed nor expressed that view but was held responsible as if he had, because that is how some listeners might have interpreted his remarks. ${ }^{45}$

It was unclear whether the Supreme Court would take a different approach to fair comment, or show the same solicitude for reputation in WIC Radio as in Church of Scientology. In finding for the defendants, Binnie J.'s majority opinion spoke of balancing an overly solicitous regard for personal reputation against the risk of allowing reputation to become "unavoidable road kill on the highway of public controversy". ${ }^{4}$ Unlike Cory J., who found little or no redeeming value in defamatory statements, Binnie J. readily supported "freewheeling debate" on matters of public interest, and recognized that the tort, as defined, had a chilling effect which led to "inappropriate censorship and self-censorship" ${ }^{47} \mathrm{He}$

41 Id., at 1088 (stating, per Ritchie J., that fair comment does not apply where "there is no evidence as to the honest belief of the writers of the letter, and the newspaper and its publisher have disavowed any such belief on their part").

$42 \quad$ See R. Martin, "Libel and Letters to the Editor" (1983-84) 9 Queen's L.J. 188 (commenting on Cherneskey and reporting that by 1980 four provinces and two territories had passed legislation to overrule the decision).

43 [2006] B.C.J. No. 1315, 55 B.C.L.R. (4th) 30 (B.C.C.A.)

$44 \quad$ WIC Radio, supra, note 11 , at para. 10.

$45 \quad I d$., at para. 9 (describing Mair's testimony that no imputations of violence by Simpson were either intended by him or in fact made by him). At the B.C. Court of Appeal, Southin J.A. also denied Mair the benefit of fair comment because a factual foundation is a requisite element of fair comment, and she found that there was no factual foundation for the imputation that Simpson would condone violence; id., at para. 13 (summarizing Southin J.A.'s reasoning).

$46 \quad I d$., at para. 2.

$47 \quad I d$., at paras. 2 and 15 
was prepared to adjust the balance on expressive freedom's side of the ledger, but not through the agency of the Charter. In that regard he followed Church of Scientology in describing the litigation as a "private law case that is not governed directly by the [Charter]", 48 and otherwise made limited reference to the Charter. ${ }^{49}$ Also, citing Dagenais for the proposition that there should be no hierarchy of values enabled him to treat reputation as expressive freedom's equal, though it is not. ${ }^{50}$

On the merits, Binnie J. was strongly opposed to any proposal to eliminate the honest belief requirement. Once he described it as the "cardinal test" of fair comment, it followed that abolishing honest belief could not be regarded as an instance of incremental change. ${ }^{51}$ In defending this part of the fair comment doctrine, he reflected that a standard of reasonableness or proportionality for comments and opinions might be less favourable for expressive freedom than a requirement of honesty. In any event, he noted that the requirement rested on the view that it is "not too much to ask a defamer to profess an honest belief in his or her defamatory comment". ${ }^{52}$ In principle, the law gives effect to expressive freedom on matters of public interest "[i]f the speaker, however misguided, spoke with integrity" ${ }^{53}$ The suggestion that fair comment only protects those who speak with integrity is foreign to any version of the common law that is informed by the Charter.

It is clear that Binnie J. viewed subjective honest belief as a justifiable restriction on expressive freedom. After finding that Mair's editorial "clearly defamed" the plaintiff Simpson, he stated that "it was entirely proper to have Mair go into the witness box to affirm his honest belief in what he had said about her". ${ }^{54}$ Though proper, it was nevertheless unfair because the editorial's "sting" — that the plaintiff condoned violence could only be attributed to Mair by imputation. Preventing that fairness was a simple matter of adopting the Cherneskey dissent and substituting an objective standard for the majority opinion's subjective test. As a result, the question in WIC Radio was not whether the defendant honestly

\footnotetext{
$48 \quad$ Id., at para. 2.

49 Id. But see para. 16 (recognizing that Canadian courts have "frequently pointed to the need to develop the common law in accordance with Charter values").

50 The difference between the two is that freedom of expression is explicitly protected by s. 2(b) of the Charter, and reputation is not. It is only by viewing the text as irrelevant that the two values can be treated as equivalent.

$51 \quad I d$., at para. 36 (stating, "I do not think abolition of the requirement of honest belief, however formulated, would be "incremental"').

$52 \quad$ Id., at para. 39.

$53 \quad$ Id., (emphasis added).

$54 \quad I d$., at para. 45.
} 
believed the defamatory comment, but whether any person could honestly hold that opinion. ${ }^{55}$ Justice Binnie thought that this improvement to the fair comment doctrine would accommodate expressive freedom, as few comments would fail the "any man" version of honest belief. $^{56}$

Meanwhile, LeBel J. joined issue at the level of principle and wrote an iconoclastic concurrence which took aim at key elements of the common law doctrine. Without challenging the trial judge's finding, he nonetheless registered his disagreement with the conclusion that the editorial was prima facie defamatory. ${ }^{57}$ In making that argument LeBel J. observed that opinions are not like facts; they are not taken at face value; they may or may not be believed; and, they may or may not be defamatory. ${ }^{58}$ From that perspective, the question is not whether the words impute negative qualities to an individual, but whether the public would think less of that person because of the comment. ${ }^{59} \mathrm{He}$ found, in the context of WIC Radio, that Mair's comments "would likely not have led 'right-thinking' members of the public to think less of Simpson", and posed "no realistic threat" to her reputation. ${ }^{60} \mathrm{He}$ concluded that if Mair's editorial was caught by the traditional test, then it should be modified to reflect current values, including section 2(b)'s protection of expressive freedom. ${ }^{61}$

While other members of the Court were content to adopt the preCharter dissent in Cherneskey, LeBel J. was willing to re-think the fundamental assumptions of fair comment and modify the doctrine in response to the Charter's requirements. ${ }^{62}$ In his view, the honest belief

55 The test, as articulated by Binnie J. is whether "anyone could honestly have expressed the defamatory comment on the proven facts"; id., at para. 49 (heading). The question in WIC Radio was whether "the defamatory imputation that Kari Simpson 'would condone violence toward gay people' is an opinion that could be held by an honest person in the circumstances"; id., at para. 61 .

$56 \quad I d$., at paras. 40,48 , and 50 .

$57 \quad$ Id

58 Justice LeBel cautioned that courts should not be "too quick" to find defamatory meaning, especially in the case of opinions: $I d$., at para. 69. He explained that "[i]t would quite simply be wrong to assume that the public always takes statements of opinion at face value" (id., at para. 73), and concluded that "it cannot be consistent with the Charter value of freedom of expression to treat spirited statements of opinion in a debate on matters of public interest as being prima facie defamatory" (id., at para. 79).

Id., at para. 69 (proposing a list of relevant factors which includes whether the words are a statement of opinion rather than a statement of fact; how much is publicly known about the plaintiff; the nature of the audience; and the context of the comment).

$60 \quad I d .$, at paras. 69 and 78

$61 \quad I d$., at para. 79.

62 Justice Rothstein concurred in LeBel J.'s abolition of honest belief, but not his views about the standard for prima facie defamation: id., at paras. 108-112. 
element "no longer offers anything of value" in balancing interests, and it is "no longer justifiable" to judge comment or opinion "on an objective basis". ${ }^{63}$ He reasoned that if an objective standard cannot ask whether a belief is reasonable without encroaching on expressive freedom, ${ }^{64}$ then it is reduced to a requirement that the belief have a basis in facts. ${ }^{65}$ But nor did it make sense to define belief that way, because fair comment presupposes a factual foundation, and duplicating it as an aspect of honest belief provides no additional protection for reputation. ${ }^{66}$ Essentially, LeBel J. concluded that, no matter how it was defined, honest belief was incoherent: any content-based standard of reasonableness was impermissible, and any other objective requirement, such as a foundation in facts, would duplicate an existing element of the doctrine. ${ }^{67}$

Justice LeBel held that eliminating honest belief was an incremental change that the Court had the power and responsibility to make, because the common law had fallen "out of step with its underlying principles and with modern values", and the test had proved to be "unworkable or to serve no useful purpose". ${ }^{68}$ Under his approach, fair comment would be available on proof that the words were a comment and not a statement of fact, on a matter of public interest, and were grounded in the facts. ${ }^{69}$

Justice Binnie's majority opinion recognized that Cherneskey was unacceptable, but nonetheless protected the traditional concept of fair comment from change. On the positive side, he endorsed an objective standard and eliminated "fairness" from the fair comment doctrine. As a

$63 \quad$ Id., at para. 85 .

$64 \quad$ Id., at para. 99 (stating that "a requirement of objective honest belief is an inappropriate one, in that it places a reasonableness restriction on the opinions a person may legitimately express").

Justice LeBel reasoned that "[i]f the speaker's prejudices or inclination toward exaggeration and obstinacy are irrelevant, it would similarly be irrelevant to consider the objective reasonableness of the comment aside from the requirement that it have a basis in fact": id., at para. 90 (emphasis added).

${ }_{66} I d$., at para. 94 (arguing that "the only justifiable remnant" of this element is a requirement that the comment be based on known facts, and the Canadian doctrine already includes a "based on true facts element that is independent of concerns about whether an honest person could hold the opinion").

67 In terms of the relationship between the subjective and objective, LeBel J. maintained that the requirement that a person be capable of believing the comment, given the facts, would not eliminate the problem of assessing the objective reasonableness of the comment. If it is not a basis in facts test, it is unclear how the "any person" test could determine objective belief without resort to a standard of objective reasonableless: $i d$., at para. 91 .

$68 \quad$ Id., at para. 94.

69 Although the CCLA also proposed a shift in the burden of proof, LeBel J. essentially adopted its position on the doctrinal questions: that honest belief be eliminated and that fair comment be based on three criteria; comment, on a matter of public interest, that is based in facts. 
result, it is clear that although comments must be honest they need not be fair. ${ }^{70}$ Even so, it is disappointing that the Court was so insistent on preserving a traditional conception of fair comment. Half measures, like the substitution of an objective honest belief, may improve the common law but leave expressive freedom at risk just the same.

Not long after WIC Radio, the Court disregarded Binnie J.'s remarks about incremental change and created a new defence in the law of defamation. Though the introduction of "public interest responsible communication" - or PIRC - also represents an improvement in the common law, it could hardly be otherwise under Scientology. Here, as well, then, the key question is whether Grant's PIRC defence provided expressive freedom the protection that is required by the Charter.

\section{GRANT AND CUSSON: FREEDOM OF "RESPONSIBLE COMMUNICATION"}

At first impression, the Supreme Court's decisions in Grant and Cusson look like significant victories for the media. ${ }^{71}$ After years under Scientology's yoke, redemption for expressive freedom arrived in the form of a defence that is available to those who publish false, defamatory statements, but can show that the content addresses a matter of public interest and that the publisher meets a standard of responsible communication. ${ }^{72}$ This is how the Court's concept of "public interest responsible communication" fundamentally changed the law without disturbing precedent.

The Court realized in these cases, as it had in WIC Radio, that the status quo could not continue. Following Church of Scientology, Canada's defamation law did not even keep tempo with common law developments in countries without constitutional rights. For that reason, the key question in Grant and Cusson was not whether, but how, the Court would respond to the imperative for change. Working within the framework of existing doctrine was undesirable, because it would require the Court to engage precedent and address Scientology's refusal to modernize the defence of qualified privilege. The U.K.'s Reynolds doctrine

$70 I d$., at para. 28 (stating that "the addition of a qualitative standard such as 'fair-minded' should be resisted"); id., at para. 40 (noting that "the operative concept is 'honest' rather than 'fair' lest some suggestion of reasonableness instead of honesty should be read in"); and at para. 48 (quoting Dickson J.'s observation that "the objective limits of fairness ... are very wide").

71 Supra, note 4.

72 Id., at para. 126 (summarizing the two steps of the PIRC defence). 
was attractive because it offered the path of least resistance: a way for the Court to atone for Church of Scientology and correct its draconian consequences for expressive freedom. ${ }^{73}$ By presenting PIRC as a new defence, unrelated to qualified privilege, the Court was able to emasculate Scientology and yet leave the decision in place.

The concept of responsible journalism did not exist when Church of Scientology was decided. The central question at that time was whether the Court should constitutionalize the common law by adopting the Sullivan rule. As discussed, Cory J. reacted strongly to the suggestion that false, defamatory statements should be constitutionally protected. The dynamics shifted with the passage of time, developments in other jurisdictions, and the Ontario Court of Appeal's endorsement of responsible journalism. ${ }^{74}$ By 2009 there was little pressure to draw on first amendment doctrine, with its reputation for absolutism, or to rebuff Sullivan's malice rule, which set the balance too firmly on the free speech side. The concept of responsible journalism appealed to the Court's sense of compromise because it represented the "middle road" between the unmodified common law and the first amendment's constitutionalization of defamation law. ${ }^{75}$

In adopting the Reynolds doctrine the Court renamed it as responsible "communication", to remove its focus on journalism and open the defence up to all manner of speakers. ${ }^{76}$ In striking contrast to Church of Scientology - which treated the expressive activity as valueless - the Chief Justice's majority opinion in Grant explained how section 2(b)'s underlying values support the public's interest in information that is false or inaccurate, as well as defamatory. ${ }^{77}$ This discussion informed the first part of Grant's test, which asks whether the statements at issue address a matter of public interest. In doing so it incorporated constitutional values

73 Reynolds, supra, note 10, and Church of Scientology, supra, note 9. Though McLachlin C.J.C. was the only judge in Grant and Cusson who also participated in Church of Scientology, the Court was reluctant to overrule that decision.

${ }_{74}$ See Grant v. Torstar Corp., [2008] O.J. No. 4783, 92 O.R. (3d) 561 (Ont. C.A.); and Cusson v. Quan, [2007] O.J. No. 4348, 87 O.R. (3d) 241 (Ont. C.A.).

75 Grant, supra, note 4, at para. 85.

${ }^{76}$ Id., at paras. 96-97.

77 See "The Argument from Principle", id., at paras. 41-65 (stating, at para. 52, that "the first two rationales for free expression squarely apply to communications on matters of public interest, even those which contain false imputations", and at para. 57, that

[i]t is simply beyond debate that the limited defences available to press-related defendants may have the effect of inhibiting political discourse and debate on matters of public importance, and impeding the cut and thrust of discussion necessary to discovery of the truth. 
into this part of the test and gave the public interest a generous and purposive interpretation. ${ }^{78}$

The second part of the defence addresses the question of responsible communication, which is based on the assumption that those engaged in public interest debates should be held accountable for not acting carefully. ${ }^{79}$ To promote that objective, the Chief Justice proposed a list of seven non-exhaustive criteria to determine whether a communication is "responsible", in the circumstances. ${ }^{80}$ Though abbreviated from the U.K.'s 10-step test, the Supreme Court's checklist is otherwise indistinguishable from its British progenitor. ${ }^{81}$

Even before the Charter is taken into account, there is reason to doubt that Grant's touchstones of responsible communication will protect expressive freedom. The Court itself acknowledged that the concept encountered resistance in the U.K., and provided an excerpt which stated that "the Reynolds defence virtually never succeeded". ${ }^{22}$ The Chief Justice noted that the early history of the doctrine prompted the House of Lords to intervene in Jameel v. Wall Street Journal and urge the lower courts to give responsible journalism an interpretation that protected the rights of the media. ${ }^{83}$ After describing those problems and doubts, she went on to embrace the Reynolds doctrine uncritically, and essentially without modification. ${ }^{84}$ Unless it is applied in a different way, there is

78 Id., at paras. 98-109. At para. 106 she stated that " $[\mathrm{t}]$ he public has a genuine stake in knowing about many matters, ranging from science and the arts to the environment, religion, and morality", and added that "[t]he democratic interest in such wide-ranging public debate must be reflected in the jurisprudence".

$79 \quad I d$., at para. 62 (stating that "[p]eople in public life are entitled to expect that the media and other reporters will act responsibly in protecting them from false accusations and innuendo", and that "[a] defence based on responsible conduct reflects the social concern that the media should be held accountable through the law of defamation").

80 Id., at paras. 111-126.

81 Though Reynolds provides a longer list, Grant treats the British factors dealing with the plaintiff's side of the story as one element, not three. Other differences do not appear, on first impression, to signal notable differences divergences between the two standards.

82 Id., at para. 71, quoting D. Hooper, "The Importance of the Jameel Case" (2007) 18(2) Ent. L.R. 62, at 62 [hereinafter "Hooper"].

83 Id., at paras. 72-74. See Jameel, supra, note 10, at para. 56 (per Lord Hoffman, stating that the 10 factors "are not tests which the publication has to pass", though "[i]n the hands of a judge hostile to the spirit of Reynolds, they can become ten hurdles at any of which the defence may fail"). See Hooper, id.; K. Beattie, "New Life for the Reynolds 'Public Interest' Defence? Jameel v. Wall Street Journal Europe" (2007) 1 E.H.R.L.R. 81-89.

84 Grant, supra, note 4, at paras. 69-74. The Chief Justice noted that Jameel "has been welcomed as re-affirming the liberalizing tone of Reynolds and providing much-needed guidance for its application", before stating, inconclusively, that "questions remain": id., at para. 74. 
little reason to predict that the Supreme Court's PIRC defence will do a better job of protecting expressive freedom than its British counterpart. ${ }^{85}$

Traditionally, the risk associated with the publication of false or inaccurate information fell squarely on expressive freedom. Subject to the defence of privilege, reputation received complete protection at common law when the truth of defamatory statements was not, or could not be, proven. Over time, courts slowly recognized that the risk of error was an unavoidable and necessary cost of public debate, and took steps to redress the imbalance in common law doctrine. Whether the Charter directly applies or not, the Court has consistently held that the common law must evolve in step with the Charter and its values. ${ }^{86}$ The question in this instance is whether the Court's response satisfies section 2(b)'s requirements. The PIRC defence is conceptually and doctrinally a British mechanism, and though the public interest element is acceptable, the rest of the test and its standard of responsible communication neither considers nor reflects the constitutional requirements of expressive freedom. The Chief Justice claimed that the Court's choice was "buttressed by the argument from Charter principles", but failed to explain how Grant's replica of responsible journalism responds to the Charter. ${ }^{87}$

One problem is that the PIRC defence is poorly designed to protect expressive freedom. In structural terms, the two parts of the test are not in balance. The public interest element involves the judge and jury, but applies a generous and relatively straightforward test to determine, in the first instance, whether the defence is engaged. A prima facie finding on that issue is followed by the second part of the test, which conducts a complex and extensive analysis on the question of responsible communication. The purpose of this step is not to protect expressive freedom but to make it as difficult as possible for it to prevail. ${ }^{88}$ It is not difficult to see that attention will focus on that issue, with the result that the public interest and its connection to section 2(b)'s underlying values, will be overshadowed, or even forgotten, in the process. Another problem is that

85 For a thorough pre-Jameel assessment of Reynolds, see R. Weaver, et al., "Defamation Law and Free Speech: Reynolds v. Times Newspapers and the English Media" (2004) 37 Vand. J. Transnat'1 L.J. 1255.

86 Grant, supra, note 4, at para. 44 (stating that "[t]he constitutional status of freedom of expression under the Charter means that all Canadian laws must conform to it" and that the common law, "though not directly subject to Charter scrutiny where disputes between private parties are concerned, may be modified to bring it into harmony with the Charter") (emphasis added).

$87 \quad$ Id., at para. 86.

88 According to Hooper, "the Reynolds defence virtually never succeeded because the 10 pointers of responsible journalism were treated by the judges as hurdles to be surmounted" (emphasis added). Supra, note 82. 
the new defence places the onus on those whose statements have constitutional value to establish that they meet a standard of responsible communication. The reverse onus may be part of defamation law's regime of strict liability, but it is contrary to general principles of tort law, as well as to the principle that infringements of expressive freedom must be justified.

In addition, the concept of responsible communication is difficult to reconcile with the Court's approach to fair comment in WIC Radio. There, the Court eliminated fairness from the doctrine, because retaining that requirement was patently inconsistent with a commitment to wideranging debate on matters of public interest. ${ }^{89}$ Though defamatory opinions can be as irresponsible as false statements of fact, it did not take the Court long after its decision in WIC Radio to endorse "fairness" as the guiding principle of responsible communication. Whereas irresponsibility short of malice is not actionable under WIC Radio, false or inaccurate statements are actionable under Grant unless the publisher can prove due diligence. In failing to explain why fairness was eliminated from fair comment, only to become the touchstone of responsible communication, the Court seemed unaware of the inconsistency.

The deeper problem is that, in principle, the criteria of responsible communication are at odds with the fundamental assumptions of the section 2(b) jurisprudence. Nowhere else is the exercise of expressive freedom subject to a standard such as Grant's; expression can be limited when it causes harm, but not simply because it is unfair or irresponsible. From that perspective, the movement to a standard of fairness, responsible conduct and due diligence represents a significant shift, not only in defamation law but, more generally, in the section 2(b) jurisprudence. ${ }^{90}$ In place of the harm principle, which determines the justifiability of limits on expressive freedom, the Court adopted a standard of fairness and responsibility. Not only did Grant depart from principle with that standard, the Court also incorporated privacy concerns into its conception of responsible communication. ${ }^{91}$ Adding the protection of privacy further obscures the publication of false statements as the basis of the tort and, in

\footnotetext{
$89 \quad$ Supra, note 70.

90 The Court used the following language, repeatedly and consistently, to express its standard of responsible communication: it spoke of diligence, reasonable diligence, reasonable steps, fairness, and responsible conduct, and contrasted these qualities with irresponsible reporting and actions which are inherently unfair. Grant, supra, note 4, at paras. 111-126 (discussing the elements of responsible communication). analysis).
} 
doing so, poses a risk that individuals will be held liable for privacy violations which would not have been actionable under the pre-Grant rules of defamation law. ${ }^{92}$

Meanwhile, the Court's discussion of qualified privilege was limited to an explanation of the reasons responsible communication should be viewed as a new defence. ${ }^{93}$ Essentially, the difficulty with a single defence was that qualified privilege and responsible journalism ask different questions and give different answers. For instance, the Chief Justice noted that qualified privilege rests on a principle of reciprocal duty and interest which is not grounded in expressive freedom's values, and does not translate to the concept of publication to the world at large..$^{94}$ She also found responsible journalism's focus on due diligence an "uneasy fit" with a defence that can be defeated by malice. ${ }^{95}$ Finally, it is the occasion on which publication occurs that determines the existence of a privilege, and though the defence can be defeated by malice, the publisher's conduct - and whether fair, unfair, or otherwise - does not matter. ${ }^{96}$ By contrast, the PIRC defence turns on whether the publisher's actions are responsible or irresponsible. ${ }^{97}$

It is true that qualified privilege, as traditionally construed, placed constraints on the availability of the defence, but it does not follow that responsible communication is the answer. In that regard, it is unfortunate that the Court did not consider an alternative which would recognize a public interest privilege or defence for publications at large. Under an approach along such lines, statements which satisfy the public interest criterion could prima facie be protected, but still be actionable where the plaintiff establishes harm to reputation. On that issue, the PIRC's standard of due diligence, fairness, reasonableness and responsible conduct sets too low a threshold to protect expressive activity which has constitutional value. ${ }^{98}$ It is more consistent with Charter values to require the plaintiff to establish subjective fault; in this context, that means showing that the defendant knew the material was false, or was reckless in

92 Though truth remains a complete defence, the point is to draw attention to the incorporation of privacy into a tort that has traditionally been associated with harm to reputation. Despite overlap between the two, the law of defamation previously did not protect privacy interests.

93 See $i d$., at paras. 88-95.

$94 \quad$ Id., at paras. 93 and 94

95 Id., at para. 92 (suggesting, essentially, that malice is irrelevant under the PIRC defence because the requirements of responsible communication cannot be met when malice is present).

$96 \quad I d$. , at para. 90.

$97 \quad I d$

98 Supra, note 90. 
publishing it without knowing whether it was true or false. A doctrine of this kind chooses a point between PIRC's objective criteria and malice at common law; it sets a higher threshold than responsible communication, and a lower one than malice, which is defined, at common law, as having a dominant motive of spite or ill will, or otherwise having an indirect motive or ulterior purpose. ${ }^{99}$ Under this alternative, fault is based on what the publisher knew about the accuracy of the statements, and is otherwise not concerned with whether the publisher has been responsible or not.

There are several reasons a public interest privilege or defence based on a standard of subjective fault is preferable to Grant's PIRC defence. First of all, the proposal is consistent with the values, requirements and structure of the Charter. It replaces qualified privilege's outdated concept of duty with a definition of the public interest that is in keeping with section 2(b)'s values. A public interest defence affords protection for expressive freedom but also vindicates reputation where the defendant harms the plaintiff's reputation. For these purposes, harm takes the form of subjective fault which focuses on the publisher's knowledge, and not on whether the publisher has been fair or not. This alternative also fits the Charter's analytical structure: a statement that addresses a matter of public interest is prima facie protected, and it is up to the plaintiff to demonstrate why reputation should prevail over expressive freedom, in the circumstances. This is more consistent with the Charter than the PIRC defence, which places the burden on a publisher to disprove negligence and to establish that a communication was fair and responsible. A further advantage is that modifying qualified privilege along these lines would have avoided introducing a defence that has not been especially successful in the U.K. A public interest defence or privilege would minimize the changes to the common law and offer a doctrine that is consistent with Charter values.

It is unfortunate that the Court chose not to modify the traditional defence, as qualified privilege could have been redefined to comply with Charter values. Though doing so would require the defence to be liberated from the traditional concept of "duty", the Court had the authority to take that step. This approach could have set Canada's defence apart and done a better job of harmonizing the common law and the Charter. Yet in

99 The proposal essentially adopts Sullivan's definition of actual malice, but refers to it as subjective fault to avoid confusing subjective fault in this context with the common law definition of malice. For a definition of malice at common law, see WIC Radio, supra, note 11, at para. 101. 
its zeal to embrace a ready-made solution that sidestepped Church of Scientology, the Court chose to follow rather than to lead. As a result the Charter played a visible role in Grant but one that was more gestural than substantive, or prescriptive, in nature.

Though Grant diminished the severity of Scientology's consequences for expressive freedom, the PIRC defence has shifted debate to the concept of responsible communication and what that means. Protecting false, defamatory statements which serve the public interest now depends on how the Grant criteria are applied. And though the PIRC defence does not incorporate Charter standards or doctrines, the Charter can make a difference in the way responsible communication is interpreted. For example, the courts can take care not to follow the U.K., and resist changes in the law of defamation that are aimed at correcting an imbalance that historically favoured reputation over expressive freedom. In Grant the Court made it clear that the PIRC defence is informed by and responsive to Charter values. That not only distinguishes it from Reynolds, but also mandates that Canada's defence must evolve in a way that reflects that vital difference.

The first step of the Grant test can assist in promoting that objective. Statements which serve the public interest not only engage the defence but, in doing so, speak to section 2(b)'s values. As such, the prima facie finding on that issue provides a context for the analysis of responsible communication. In particular, the courts should be careful not to treat the elements of that test as a series of hurdles for expressive freedom to clear. ${ }^{100}$ Instead, they should require clear and convincing evidence before reaching any conclusion that a publisher has acted irresponsibly in publishing statements that are in the public interest. Any other approach would deny expressive freedom the protection that is required by the Charter.

\section{R. V. NATional Post: "COGENT OBJeCtions" to CONSTITUTIONAL IMMUNITY ${ }^{101}$}

To this point, the article has shown that the Court was unwilling to let the Charter play a more direct role in the evolution of defamation law. That may be partly because the Court continues to view expressive freedom and reputation as equals. Section 2(b) of the Charter altered that

\footnotetext{
$100 \quad$ Supra, note 88.

101 National Post, supra, note 16, at para. 43
} 
equation by granting expressive freedom constitutional status, and that change in status should be reflected in the structure of doctrine. Though the Court supported section 2(b)'s values in WIC Radio and Grant, the Charter had little influence on the doctrines that were adopted in these cases.

Early in 2010, National Post dealt with journalist-source privilege and the decision is discussed briefly, to reinforce the Court's pattern of decision-making in cases where common law doctrine infringes section 2(b)'s guarantee of expressive freedom. The question in National Post was whether the common law's four-part test for privilege violated the Charter, in the context of journalist-source relationships and the newsgathering process. The Wigmore test, as it is known, predates the Charter and was not designed to protect relationships which have constitutional status, such as those arising from section 2(b)'s guarantee of expressive and press freedom. At common law, the party seeking to protect the confidentiality of a relationship has the burden to establish the privilege under all parts of the test, including the balancing of values which determines whether to compel disclosure or protect the integrity of the relationship. ${ }^{102}$

The issue in National Post was whether a newspaper and its reporter could invoke section 2(b) of the Charter against a writ of assistance and search warrant which, if executed, would disclose the identity of a confidential newsgathering source. ${ }^{103}$ As a matter of principle, the fundamental question was whether the Wigmore test required modification to safeguard the newsgathering process and access to confidential sources. Previously, the Court had held that newsgathering is constitutionally protected, and had also recognized the importance of reporters' access to confidential sources. ${ }^{104}$ Regardless whether the privilege was protected in this instance,

102 Under the Wigmore test, those claiming the privilege have the burden to establish four criteria: first, the communication must originate in a confidence; second, the confidence must be essential to the relationship between the parties; third, the relationship must be one that should be sedulously fostered in the public good; and fourth, once those requirements are met, the interests served by protecting the relationship must outweigh the interest in getting at the truth in the litigation at stake. M. (A.) v. Ryan, [1997] S.C.J. No. 13, [1997] 1 S.C.R. 157 (S.C.C.).

103 National Post, supra, note 16, at paras. 8-24 (explaining the facts surrounding the source, the news story — which potentially implicated then Prime Minister Jean Chrétien — and the proceedings relating to the search warrant and writ of assistance).

104 Canadian Broadcasting Corp. v. New Brunswick (Attorney General), supra, note 15, at para. 26, per LaForest J., stating that "measures that prevent the media from gathering ... information, and from disseminating it to the public, restrict the freedom of the press"; and National Post, supra, note 16 , at para. 30, stating that "[t]he courts have long accepted the desirability of avoiding where possible putting a journalist in the position of breaking a promise of confidentiality" (emphasis added). 
the common law test could and should have been modified. ${ }^{105}$ The Charter was unquestionably engaged because the state, as singular antagonist, had issued coercive orders against the National Post and its reporter, who claimed that their rights under section 2(b) had been violated. In the circumstances, the Court should have separated the journalist-source privilege from the other relationships covered by the Wigmore test, and altered the test to recognize the constitutional status of the newsgathering relationship and give it adequate protection under section 2(b). ${ }^{106}$

Specifically, the Court could have fashioned a common law test specific to section 2(b), as it had earlier in Dagenais, along these lines. ${ }^{107} \mathrm{~A}$ reporter or journalist claiming its benefit would have the initial burden to establish the privilege, but once that was done the onus would shift to the party seeking disclosure to justify any infringement of the confidential relationship. The first step of such a test reflects the standard requirement that the party seeking the Charter's benefit must establish the entitlement. ${ }^{108}$ Likewise, the second step reflects the requirement, once the prima facie right is established, that the party who would violate the entitlement must justify the infringement. ${ }^{109}$ In National Post it was a matter of breaking up the elements of the Wigmore test, and remodelling them to create an issue-specific test for a newsgathering privilege that is consistent with the Charter. ${ }^{110}$

Justice Binnie's majority reasons flatly refused to modify the Wigmore test in any way. He was adamant that the common law did not

105 In the circumstances, the privilege was asserted over a piece of physical evidence - an envelope and enclosed document — which constituted the actus reus of offences of forgery and uttering a forged document that the authorities were investigating.

106 The Wigmore test has applied to a variety of relationships, which include doctor-patient, psychiatrist or psychologist-patient, religious communications between spiritual advisors and church members or followers, journalist-source, lawyer-client, and family counsellor-client. See, e.g., R. v. Gruenke, [1991] S.C.J. No. 80, [1991] 3 S.C.R. 263 (S.C.C.) (addressing the privilege between a priest and lay counsellor and a church member); M. (A.) v. Ryan, supra, note 102 (dealing with the privilege between a psychiatrist and patient); and R. v. McLure, [2001] S.C.J. No. 13, [2001] 1 S.C.R. 445 (S.C.C.) (comparing class privileges — solicitor-client, spousal and informer — with case-by-case privileges).

107 Supra, note 13.

108 Consistently with the structure of Charter analysis, the CCLA argued, at the Supreme Court hearing, that to establish a prima facie breach, the claimant would have to show that he or she was a journalist, who had acquired information in the course of gathering news, and under a promise that the journalist would protect the confidentiality of the source.

109 Several interveners at the Supreme Court of Canada argued that any violation of a confidential relationship had to be justified by the party seeking disclosure — in this instance, the state and that the requirements of the Dagenais test should be used for this purpose. See supra, note 14 (outlining the elements of the test).

110 This approach created a constitutional version of the Wigmore test which would apply specifically to the question of journalist-source privilege. 
require adjustment, and rejected the invitation to constitutionalize the Wigmore test, either in whole or in part. ${ }^{111} \mathrm{He}$ acknowledged the special position of the news media and the role confidential sources play in newsgathering, but rejected the suggestion that the journalist-source relationship engages section 2(b) or is constitutionally protected. ${ }^{112}$ Under this view the legislature could prohibit the use of confidential sources or make the disclosure of such sources mandatory, without any balancing of values. According to National Post this would not engage the Charter. In any case, Binnie J. held that "the purpose of section 2(b) can be fulfilled without the necessity of implying a constitutional immunity" and found that a "judicial order to compel disclosure of a secret source would not in general violate section2(b)". ${ }^{113} \mathrm{He}$ thought that the common law was adequate to protect section 2(b) because "[t]he public interest in free expression will always weigh heavily in the balance."114 With Abella J. dissenting, but solely on Wigmore's application to the facts, the Court held that law enforcement outweighed any interest in protecting the confidential source, and found that there was no privilege. ${ }^{115}$

In National Post, as well as in WIC Radio and Grant, the Court rehearsed section 2(b)'s underlying values and did so, presumably, to acknowledge that the Charter should make a difference. But that difference was not reflected in the doctrines that emerged in the Court's decisions. While WIC Radio rejected the proposal to abolish the honest belief requirement, Grant adopted the PIRC defence with its concept of responsible communication, and National Post refused to alter the Wigmore test. Rather than consider whether and how elements of Charter methodology could be incorporated, the Court was content to recite section 2(b)'s underlying values and then assume that those values would be sufficiently protected by common law tests and standards.

111 In his view, those who sought constitutional recognition for this privilege were asking for "some form of constitutional immunity" and were claiming that "protection of confidential sources should be treated as if it were an enumerated Charter right or freedom"; National Post, supra, note 16, at paras. 37 and 38. He replied that "this is not to say that just because they are important that news gathering techniques as such are entrenched in the Constitution", and went on to explain that "[t]here are cogent objections to the creation of such a 'constitutional' immunity": id., at paras. 38 and 40 (emphasis in original).

${ }_{112} I d$., at para. 33, specifically recognizing that "an important element in the news gathering function (especially in the area of investigative journalism) is the ability of the media to make use of confidential sources".

$113 \quad I d .$, at para. 41.

$114 I d$., at para. 65 (emphasis in original).

115 Id., at paras. 116-141 (arriving at a different conclusion on the fourth Wigmore element, which balances the interests at stake). 
That approach is disappointing in light of other decisions that have imported Charter-based concepts and standards into the common law. Though the Dagenais line of cases is the best example, it is not the only one and other decisions, such as Nova Scotia v. MacIntyre and R.W.D.S.U. v. Pepsi-Cola, should not be forgotten. ${ }^{116}$ MacIntyre predated the Charter, but used the language of justification in proposing that limits on public access to search warrants are only permissible when it is necessary to protect social values of superordinate importance. ${ }^{117}$ More recently, Pepsi-Cola applied a muscular version of Charter values to the common law, in order to place constitutionally inspired limits on the restrictions tort law placed on labour picketing. ${ }^{118}$

The difference between these cases and those is this. Whereas Dagenais, MacIntyre and Pepsi-Cola modified the common law doctrine to make it compatible with Charter values, the defamation and privilege cases recited section 2(b)'s underlying values but failed to adopt standards to ensure that the common law adequately protects expressive freedom. It is the difference between simply acknowledging expressive freedom's underlying values, and developing standards to ensure that they are adequately protected. By failing to modify the common law in a Charter-specific way, the Court's recent decisions do not meet constitutional expectations, and as a result expressive freedom remains at risk.

\section{CONCLUSION}

It would not be accurate to say that the Charter did not make a difference in the decisions discussed in this article. After playing a negative role in Church of Scientology, the Charter served more positive purposes in the Court's recent decisions. In WIC Radio, Grant, and National Post the Court provided a preliminary discussion of section 2(b) before considering the status of expressive freedom in certain common law

116 Dagenais, supra, note 13; Nova Scotia (Attorney General) v. MacIntyre, [1982] S.C.J. No. 1, [1982] 1 S.C.R. 175 (S.C.C.); R.W.D.S.U., Local 558 v. Pepsi-Cola Canada Beverages (West) Ltd., [2002] S.C.J. No. 7, [2002] 1 S.C.R. 156 (S.C.C.) [hereinafter "Pepsi-Cola"].

117 MacIntyre, id.

118 On harmonizing the common law and the Charter, Pepsi-Cola, supra, note 116, is another model decision. There, the Court held that the "starting point" in interpreting the common law to reflect the Charter "must be freedom of expression" (id., at para. 37) and then stated that "if we are to be true to the values expressed in the Charter our statement of the common law must start with the proposition that free expression is protected unless its curtailment is justified" (id., at para. 67; emphasis added). In addition, the Court made it clear in that case that limitations are only permitted "to the extent that this is shown to be reasonable and demonstrably necessary in a free and democratic society" (id., at para. 37). 
doctrines. Yet rather than structure the common law to reflect the Charter's concepts of rights and limits, or to incorporate Charter standards, the Court assumed that its discussion of values, without more, was sufficient. In other words, as long as the common law was informed by Charter values, that was enough.

In WIC Radio, the Court was unwilling to entertain the suggestion that the honest belief requirement served no valid purpose, and was inconsistent with the Charter and its commitment to uninhibited commentary on issues of public interest. Grant fundamentally changed the law of defamation but, in doing so, failed to ask whether the British standard of responsible journalism was consistent with the Charter's guarantee of expressive freedom. Instead, the Court made only minor changes to it before adopting the U.K. doctrine. Finally, the Court was adamant in National Post that Wigmore's four-part test for privilege did not require doctrinal modification. Despite the presence of coercive orders against a newspaper and journalist, the Court found that expressive freedom would be adequately protected by reading section 2(b)'s values into the Wigmore test in a flexible, ad hoc manner.

At least where expressive freedom is concerned, the Court has not taken a consistent approach to the harmonization of the common law and the Charter. Though earlier decisions constitutionalized common law tests or took other steps to ensure their compliance with the Charter, the Court did not follow suit in its cases on defamation and privilege. In these decisions the Court resisted the invitation to embrace more farreaching change; instead, it both assumed and insisted that the common law would adequately protect expressive freedom. Some progress was made in these decisions, but not enough, and additional measures are required to protect newsgathering practices. The Court's unwillingness to play a more vital role in harmonizing the common law and the Charter in this area of section 2(b) doctrine means that legislative reform must now be considered. 
